\section{Environmental Modification Inside Photoselective Shadehouses}

\author{
Steven P. Arthurs ${ }^{1}$ \\ Department of Entomology and Nematology, University of Florida, Mid- \\ Florida Research and Education Center, 2725 South Binion Road, Apopka, \\ FL 32703-8504
}

\author{
Robert H. Stamps \\ Department of Environmental Horticulture, University of Florida, Mid- \\ Florida Research and Education Center, 2725 South Binion Road, Apopka, \\ FL 32703-8504
}

Frank F. Giglia

Signature Supply Inc., 3330 E. Main Street, Lakeland, FL 33801-9414

Additional index words. colored, radiation scattering, shade cloth, dispersive, solar, red/ far-red ratio

\begin{abstract}
Shade nets are widely used to protect floricultural crops from excessive radiation, wind, hail, and birds. Although black nets are most frequently used, growers are experimenting with colored, gray, and white dispersive netting to impact vegetative vigor, dwarfing, branching, leaf variegation, and timing of flowering. We monitored environmental data inside replicated shadehouse structures $(10 \times 10 \times 3 \mathrm{~m}$ high) with full covering of red, blue, pearl, and black nets (all $50 \%$ nominal shading factor) in central Florida over 12 months. Actual photosynthetically active radiation $\left(P A R, \mu \mathrm{mol} \cdot \mathrm{m}^{-2} \cdot \mathrm{s}^{-1}\right)$ was reduced most by black nets $(55 \%$ to $60 \%$ shading factor depending on the season) and least under red nets $(41 \%$ to $51 \%)$ with blue and pearl nets intermediate. Spectral analysis revealed blue nets had distinctive peaks at the blue (450 to $495 \mathrm{~nm})$ and far-red beyond $750 \mathrm{~nm}$. Red nets had a minor peak $\approx 400 \mathrm{~nm}$ and major transmittance beyond $590 \mathrm{~nm}$. Pearl nets transmitted more light above $400 \mathrm{~nm}$ compared with black nets but did not otherwise alter spectral composition in the visible range. No nets had red/far-red $(\mathrm{R} / \mathrm{FR})$ ratios $(600$ to $700 / 700$ to $800 \mathrm{~nm})$ significantly greater than ambient (close to 1$)$, whereas blue nets had a consistently lowest $R / F R$ ratio of $\approx 0.8$. Both ultraviolet- $B$ and ultraviolet-A ( 280 to $400 \mathrm{~nm})$ were reduced most by pearl nets and least by red nets. We also noted elevated temperatures and wind resistance (but not relative humidity) under colored and pearl nets compared with black, probably as a result of the different net porosities. Our study documents the different environmental modifications inside structures covered with black, colored, and photoneutral translucent nets, which will help predict or interpret specific plant responses.
\end{abstract}

An emerging approach in the production of ornamental crops is the use of photoselective (colored) and color-neutral dispersive shade netting. Modern shade nets are manufactured from woven polypropylene materials or knitted polyethylene materials with different dimensions of fibers and holes to achieve specific shade levels. Traditional black nets are completely opaque and the spectral quality of radiation is not modified by the net; hence, the shading factor is almost directly proportional to net porosity (Castellano et al., 2008a). Dispersive shade nets are less opaque and scatter radiation, creating more diffused light that can penetrate inside plant canopies

Received for publication 10 May 2013. Accepted for publication 6 June 2013.

We are grateful to Signature Supply and Polysack Plastic Industries for providing materials and Heidi Savage, Robert Leckel, and James Kerrigan for excellent technical support.

${ }^{1}$ To whom reprint requests should be addressed; e-mailspa@ufl.edu.
(Oren-Shamir et al., 2001). Colored nets contain additives that selectively filter solar radiation to promote specific wavelengths of light (Castellano et al., 2008b; Stamps, 2009).
The combination of light-scattering spectral manipulation can modify desirable plant growth characteristics. For example, compared with black nets, Aspidistra plants were more compact under red and blue nets, Philodendron grew more leaves under red and fewer under blue nets, and Pittosporum growth indices (plant height and internode length) were highest under red and gray nets (Stamps and Chandler, 2008). Oren-Shamir et al. (2001) reported branch elongation of variegated Pittosporum under the red nets and dwarfing under blue nets. Studies in Brazil showed that Phalaenopsis cultivars generally grew larger leaves under blue nets compared with black and red but showed earliest blooming under red nets (Leite et al., 2008). Additional studies indicate some beneficial aspects of colored nets for the production of fruits (Basile et al., 2008; Retamales et al., 2008; Shahak et al., 2008; Takeda et al., 2010) and vegetable crops (Ilic et al., 2012; Kong et al., 2012; Shahak, 2008) grown under red, blue, green, and yellow nets. Recent reports from Israel also suggest additional benefits of photoselective nets regarding suppressive effects on plant pests or diseases (Ben-Yakir et al., 2012; Elad et al., 2007).

However, although photoselective shade nets show promise for plant production, the variability of results among crops suggests that the physiological aspects involved in these photoresponses are not yet fully understood. Variability of results may also reflect the different optical properties of shade nets produced by different manufacturers. An additional problem is that few studies report the specific environmental conditions present under various shadehouse structures. Seasonal variation in environmental conditions inside shadehouses is expected to impact cultivation of floricultural and other crops. In addition to light, shade nets may modify environmental variables such as temperatures, wind speed, or relative humidities inside the canopy. By contrast, more studies are available on the radiometric properties of metallic thermal screens and insect screens (Cohen and Fuchs, 1999; Klose and Tantau, 2004; Nijskens et al., 1985; Papadakis et al., 2000; Soni et al., 2005).

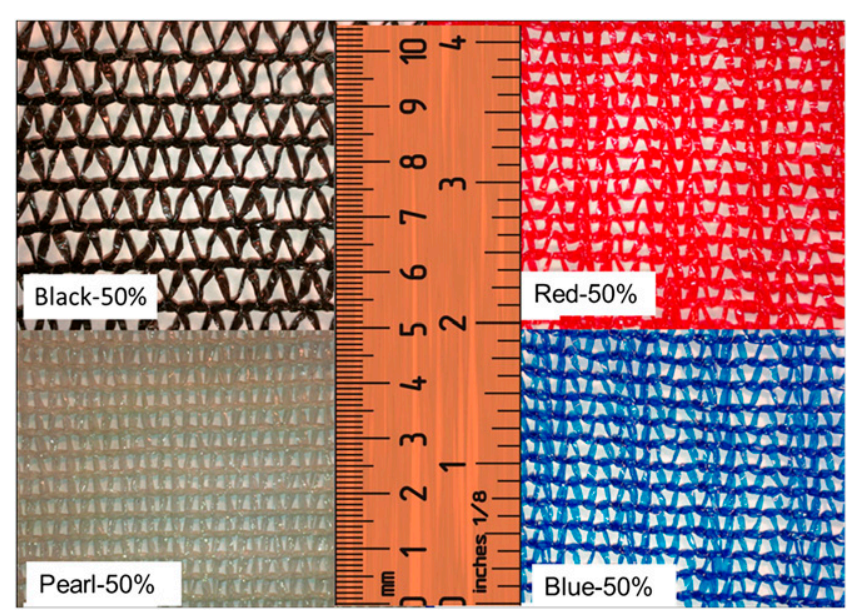

Fig. 1. Shade nets used to cover the structures at the Mid-Florida Research and Education Center. 


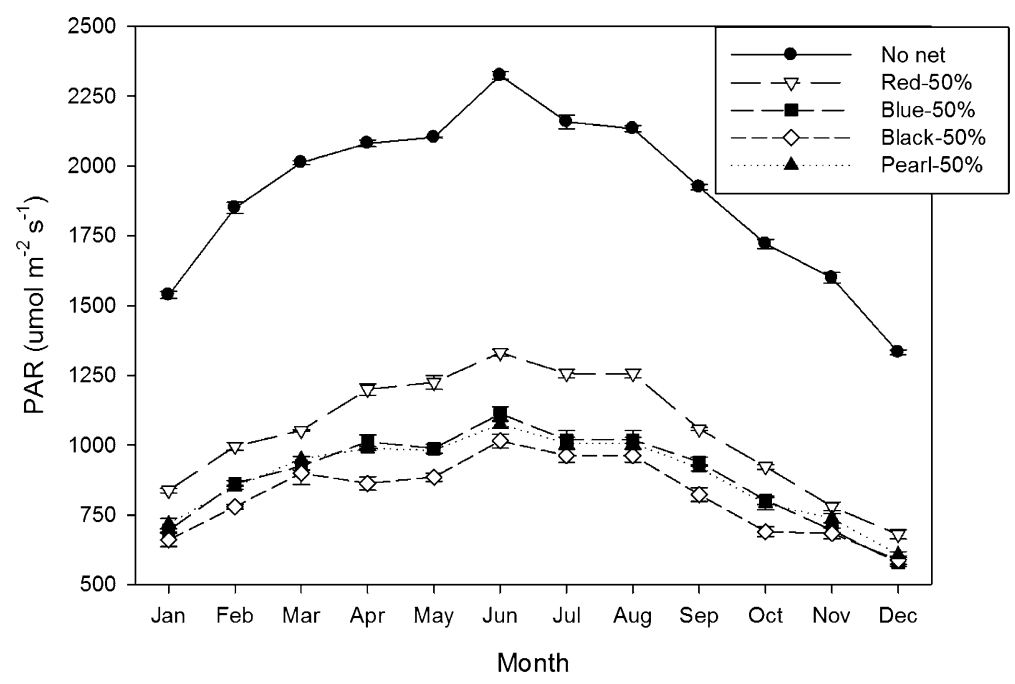

Fig. 2. Photosynthetically active radiation $(P A R)$ measured at solar noon $\left(\mu \mathrm{mol} \cdot \mathrm{m}^{-2} \cdot \mathrm{s}^{-1}, 400\right.$ to $\left.700 \mathrm{~nm}\right)$ in photoselective (red and blue) and color-neutral (black and pearl) nets. Data are means \pm SEM from four replicate houses.
Here we evaluate light quantity and quality and other environmental variables inside replicated shadehouses fitted with full-covering photoselective and color-neutral nets during a full year. This information should be of interest to growers, horticulturists, and agricultural engineers.

\section{Materials and Methods}

Study location. Studies were conducted at the Mid-Florida Research and Education Center (lat. $28.7^{\circ} \mathrm{N}$, long. $81.5^{\circ} \mathrm{W}$ ) in 2011 and 2012. Sixteen shadehouse structures (each $10.4 \times 10.4 \times 3.0 \mathrm{~m}$ height) were covered on the top and all sides with one of two photoselective (red and blue) or one of two colorneutral (black and pearl) nets (ChromatiNet ${ }^{\circledR}$; Polysack Plastic Industries, D.N. Negev, Israel; <http://www.polysack.com>) (Fig. 1). A nominal shade factor of $50 \%$ was indicated by the manufacturer for all four nets. This setup allowed us to monitor the impact of the full spectrum of environmental conditions (not just light) independently. Shadehouse structures were arranged in four blocks with
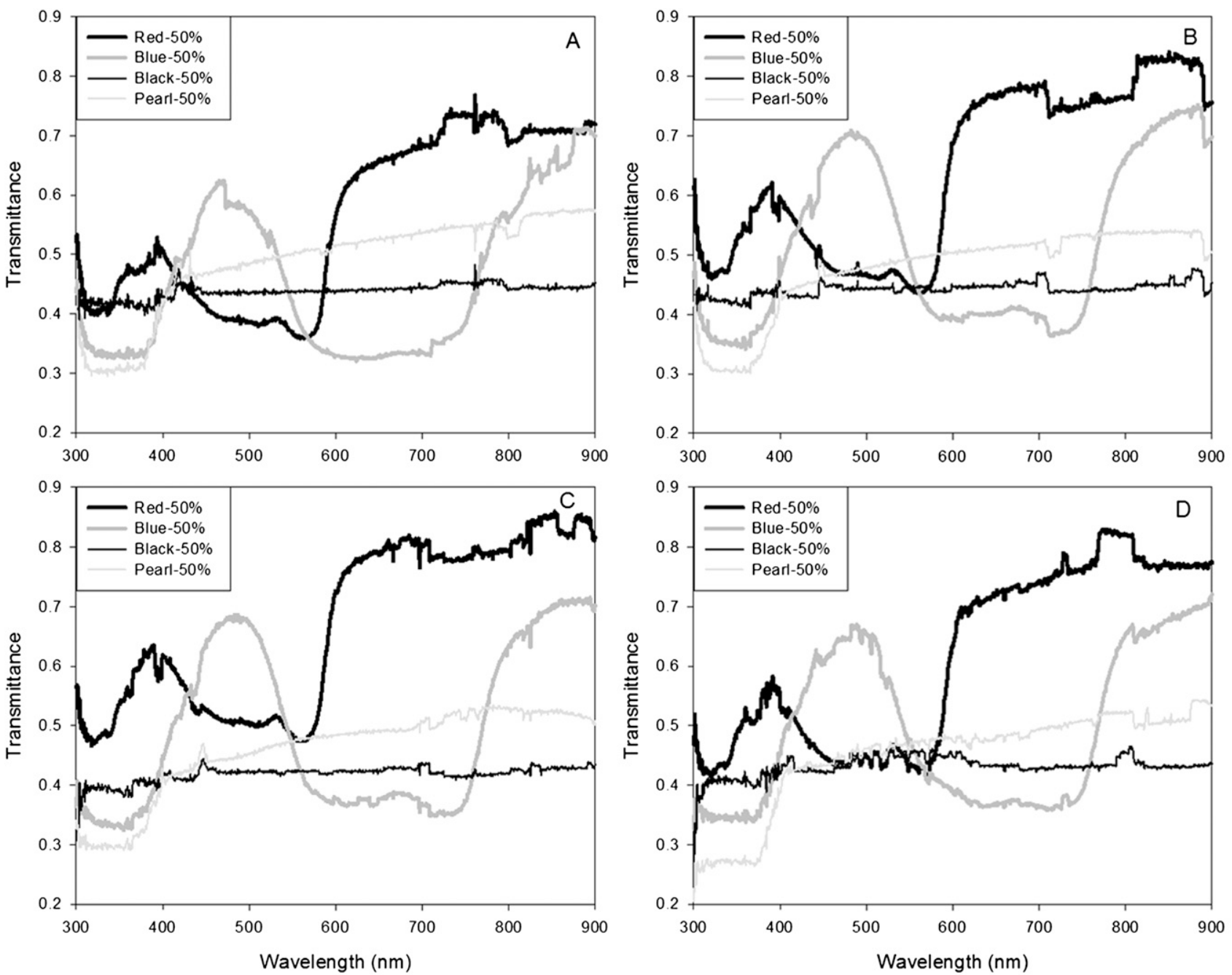

Fig. 3. Transmittance spectra of solar radiation measured under photoselective (red and blue) and color-neutral (black and pearl) nets during different seasons: January (A), April (B), July (C), and October (D). Data are the ratio between radiation $\left(\mu \mathrm{mol} \cdot \mathrm{m}^{-2} \cdot \mathrm{s}^{-1}\right)$ measured inside and outside shadehouses. Recordings were taken at solar noon and are average of four replicate shadehouses. 
each block containing all colors. The uncovered central area of each block was also used as a control (full sun) comparison.

Environmental measurements. Light measurements were taken monthly for 12 months (Sept. 2011 to Aug. 2012). PAR (400 to $700 \mathrm{~nm}$ ) was recorded with a LI-185A light meter fitted with a LI-190 quantum sensor (LI-COR, Lincoln, NE). Spectral analysis (200 to $1100 \mathrm{~nm}$ ) was measured using an optical ultraviolet/VIS spectrometer (OSM2-400 DUV; Oriel ${ }^{\mathrm{TM}}$ Newport Corp., CT). For standardization, all readings were taken in the middle of shadehouses at $1 \mathrm{~m}$ height on a clear day within $45 \mathrm{~min}$ of solar noon. Shade temperature (at $1 \mathrm{~m}$ ) was recorded hourly inside all shadehouses and uncovered areas using 20 data loggers with internal thermistors (HOBO H08-032-08; Onset Computer Corp., Pocasset, MA) placed inside a rain shield. Relative humidity during wet or overcast conditions (ambient greater than $50 \% \mathrm{RH}$ ) was recorded manually in each house on 20 separate occasions using a portable meter (Model TH-1; Amprobe, Everett, WA). Similarly, wind speed during breezy conditions (greater than $3 \mathrm{~m} \cdot \mathrm{s}^{-1}$ ) was recorded inside houses using a portable anemometer (Model 48020; Celestron LLC, Torrance, CA). All environmental readings were taken concurrently in the shadehouses and the uncovered control blocks. Where appropriate, treatments were compared through one-way analysis of variance and means separated with Tukey's honestly significant difference test at $P<0.05$ (SAS, 2008).

\section{Results and Discussion}

Photosynthetically active radiation. All shade nets reduced PAR compared with uncovered sites but there were differences between colors. Observed PAR values $\left(\mu \mathrm{mol} \cdot \mathrm{m}^{-2} \cdot \mathrm{s}^{-1}\right)$ were reduced most under black nets and least under red nets with blue and pearl nets intermediate (Fig. 2). Calculated photosynthetic shading values were black $(55 \%$ to $60 \%)$, blue $(51 \%$ to $57 \%)$, pearl $(52 \%$ to $54 \%)$, and red ( $41 \%$ to $51 \%)$, depending on the season. These results are consistent with previous work where $P A R$ was reduced less by $70 \%$ red netting compared with $70 \%$ black or $70 \%$ blue netting in unreplicated structure (Stamps and Chandler, 2008). The elevated $P A R$ in the red may be considered an artifact of the net manufacturing process, suggesting that nominal shade factor designations do not necessarily precisely determine actual PAR. The data show that although transmitted $P A R$ may be sufficient for plant growth under nets during the spring and summer months, lower values obtained during late fall and winter months may be limiting for some ornamental crops (Baloch et al., 2009; Fletcher et al., 2005).

Light quality. Spectral analysis from representative months revealed differences among nets (i.e., proportion of $P A R$ in blue, green, red, and FR spectra) (Fig. 3). Blue nets transmitted distinctive peaks in the blue ( 450 to $495 \mathrm{~nm}$ ) as well as FR/near infrared beyond $750 \mathrm{~nm}$. The red net had a minor peak $\approx 400 \mathrm{~nm}$ and major transmittance beyond $600 \mathrm{~nm}$. Pearl nets transmitted more light above $400 \mathrm{~nm}$ compared with black nets but did not otherwise alter spectral composition in the visible range compared with black nets. There were no clear seasonal trends in transmittance efficiency of the blue and red spectral peaks nor for transmittance of black and pearl nets in the PAR range (data not shown).

The effect of light quality on plants is complex involving the combined action of several photoreceptor systems with different wavelength adsorption peaks (Smith, 2000). Higher plants have receptors for blue, green, and ultraviolet light (phototropins and cryptochrome) and R/FR receptors (phytochromes). Different photoreceptors can induce distinctive morphological and physiological responses that allow adaptation to different environmental conditions (Lee et al., 2000; Schuerger et al., 1997; Stuefer and Huber, 1998). For example, several studies show that enhanced blue light can increase plant compactness, that some blue light is necessary for normal growth and development, and also that the effects of blue light appear to be speciesdependent (Cope and Bugbee, 2013). It has also been proposed that plants respond to the
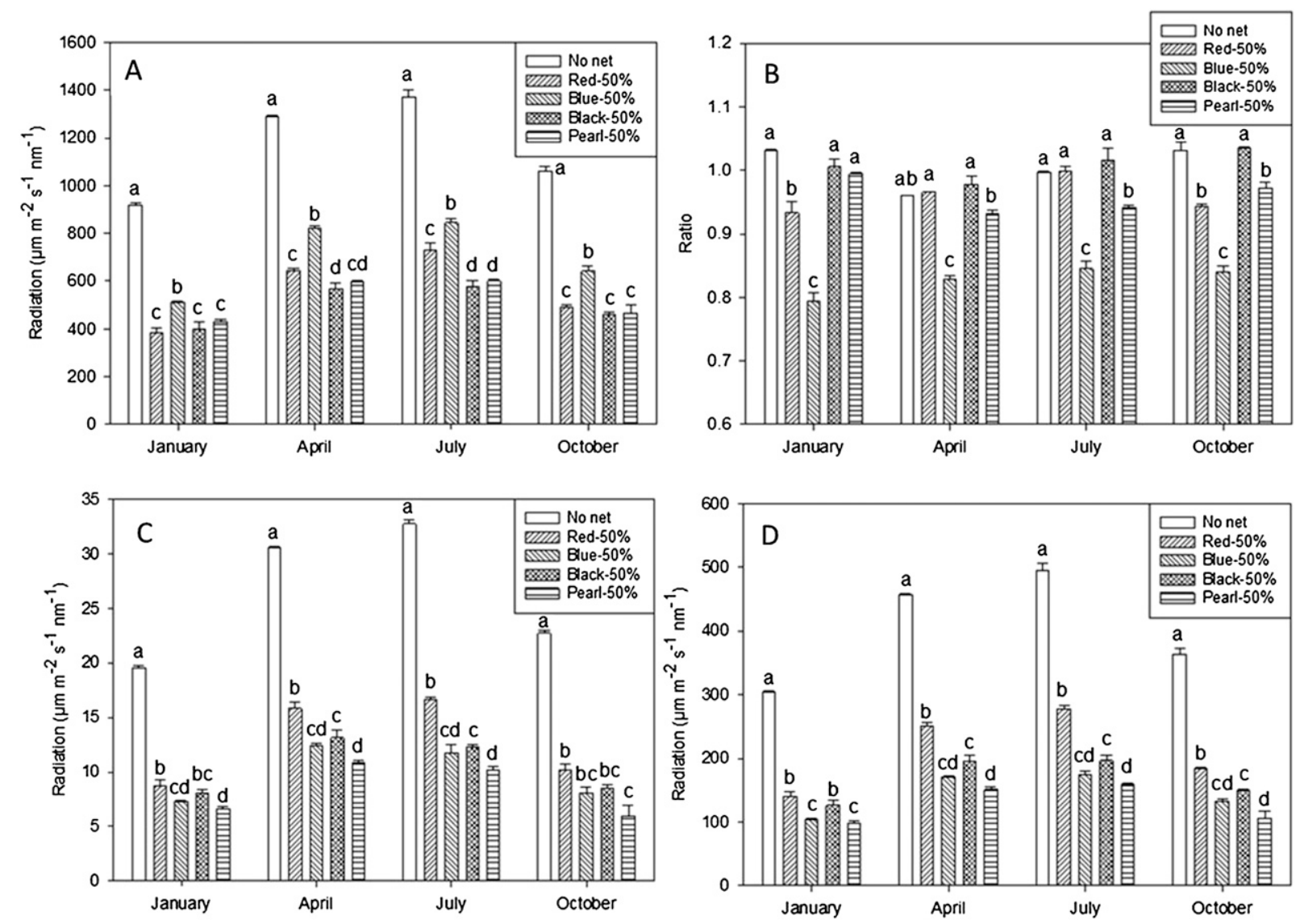

Fig. 4. Comparisons of wavelength spectra amongst shade nets. Data were measured at solar noon on clear days and integrated over ultraviolet-B, 280 to $320 \mathrm{~nm}$ (A), ultraviolet-A, 320 to $400 \mathrm{~nm}$ (B), blue, 400 to $500 \mathrm{~nm}$ (C), and red/far-red, 600 to 700/700 to $800 \mathrm{~nm}$ (D). Data are mean \pm sEM from four shadehouses; letters indicate significant differences between nets for a specific month $(P<0.05$, Tukey's honestly significant difference test). 
absolute amount of blue light rather than the relative amount of blue light in the photosynthetic range (Yorio et al., 1998, but see Cope and Bugbee, 2013). Our data showed blue nets increased light intensity between 400 and $500 \mathrm{~nm}$ over other nets by $34 \%$ to $44 \%$, depending on the season, and even more in the 450- to 500-nm range (Figs. 3 and 4A).

Manipulation of the R/FR has been proposed as a way to modify horticultural crops. For example, high R/FR ratios induce beneficial physiological responses, most notably reduced stem extension and increased plant compactness (Fletcher et al., 2005; Mata and Botto, 2009; Rajapakse and Kelly, 1992). By contrast, low R/FR ratios may cause less desirable traits such as stem elongation, strengthening of apical dominance and reduced branching (Smith and Whitelam, 1997). In our study, no nets had R/FR ratios significantly greater than ambient (close to 1), whereas blue nets had consistently lowest $\mathrm{R} / \mathrm{FR}$ ratio of $\approx 0.8$ (Fig. 4B). Red and pearl nets had statistically reduced $\mathrm{R} / \mathrm{FR}$ ratio during fall and winter and summer and fall, respectively, whereas the $\mathrm{R} / \mathrm{FR}$ ratio of black nets was never different from ambient. This finding contrasts with Oren-Shamir et al. (2001), who reported ratios of light transmitted through blue nets were the same as the natural light, whereas R/FR under red nets was slightly lower, and green net was significantly lower than that of the natural irradiation. Reduced $\mathrm{R} / \mathrm{FR}$ ratios are associated with underneath canopies of vegetation and the plant response of elongation termed the "shade avoidance syndrome." The reduced $\mathrm{R} / \mathrm{FR}$ values found under blue nets in our studies are not considered to be high enough to trigger the "shade avoidance syndrome" in most plants (Franklin and Whitelam, 2005).

Various studies also indicate that light in the ultraviolet range plays an important role in plant defenses. For example, natural or attenuated ultraviolet (especially ultraviolet-B) radiation helps protect plants from herbivores and microbial pathogens, possibly through the production of phenolic compounds and/or antioxidants (Ballaré et al., 2012; Wei et al., 2013). All shade nets reduced light intensity between 280 and $400 \mathrm{~nm}$ compared with ambient conditions, but there were differences between net colors (Fig. 4C and D). Both ultraviolet- $\mathrm{B}$ and ultraviolet-A were reduced most by pearl nets and least by red nets. In all cases, proportionally, more radiation was found in the ultraviolet-A range compared with ultraviolet-B. It has also been reported that low R/FR values (i.e., less than 1, typical of closed canopies) may lead to reduced plant defense against herbivorous insects, for example through inactivation of phytochrome $\mathrm{B}$, which regulates defense hormones (Moreno et al., 2009).

Other environmental effects. Our data show that shade nets affect environmental variables other than radiation. Temperature and $\mathrm{RH}$ impact plant growth and physiology, including disease development, in various ways (Grantz, 1990; Went, 1953). In our studies, average daily maximum air temperatures were higher inside shadehouses with colored nets compared with black nets or ambient (Fig. 5). Highest air temperatures were recorded under red (range, 1.9 to $3.7^{\circ} \mathrm{C}$ higher than black). Black nets were consistently cooler compared with ambient, recording an average $0.4{ }^{\circ} \mathrm{C}$ (range, 0.1 to $0.9^{\circ} \mathrm{C}$ ) lower daily maximum temperatures. Blue and pearl recorded similar temperatures (on average $0.2^{\circ} \mathrm{C}$ warmer for blue) and were intermediate between red and black nets. Wind speeds were different under shade nets $\left(F_{4,99}=\right.$ 182.1, $P<0.0001)$, with red, blue, and pearl providing greater wind resistance compared with black nets (Fig. 6). Because colored nets contain threads that are partially transparent, higher thread counts are needed to create the same shade factor compared with black threads, which results in smaller holes and less open area in the netting compared with traditional black nets (Fig. 1). The differences in hole sizes were sufficient to impact wind speed (and likely temperature), but not $\mathrm{RH}$ values, which remained within $\pm 1 \%$ of ambient conditions inside shadehouses and were not statistically affected $\left(F_{4,99}=0.01\right.$,
$P=0.99)$. Despite differences in relative porosity, measurements of netting mass per unit area $(\mathrm{n}=5)$ were similar among colors, i.e., $101 \mathrm{~g} \cdot \mathrm{m}^{-2}$ (pearl), $99 \mathrm{~g} \cdot \mathrm{m}^{-2}$ (black), and $95 \mathrm{~g} \cdot \mathrm{m}^{-2}$ (red and blue nets).

Use of photoselective nets. Shadenets are popular for growing ornamental plants. The most recent figures available (2011) show that $43 \%$ of floricultural crop production in the United States occurred under shade or other temporary cover (USDA/NASS, 2013). With modern mass weaving methods reducing costs, we can expect more photoselective nets to be used. Shadenet structures constructed on trellises are inexpensive compared with glass or plastic film greenhouses, which may require more solid construction and additional climate controls. Although black nets are most frequently used, growers are experimenting with colored, gray, and white dispersive netting in an attempt to impact vegetative vigor, dwarfing, branching, leaf variegation, and timing of flowering (Leite et al., 2008; Oren-Shamir

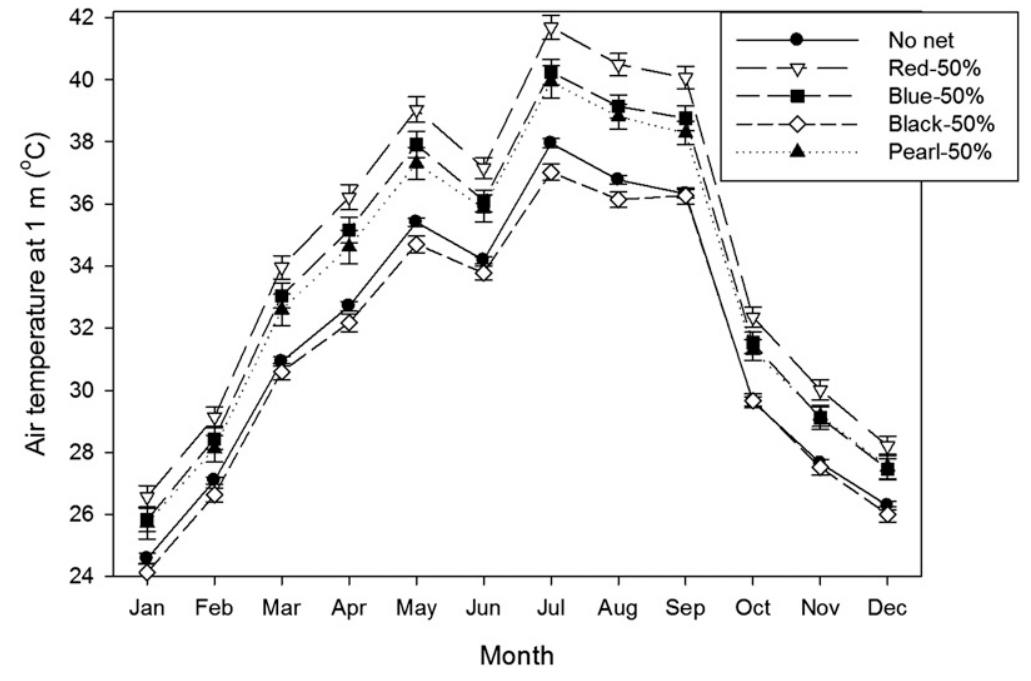

Fig. 5. Daily maximum temperatures $\left({ }^{\circ} \mathrm{C}\right)$ recorded inside and outside shadehouses. Data are means $\pm \mathrm{SEM}$ averaged over each month from four replicate houses.

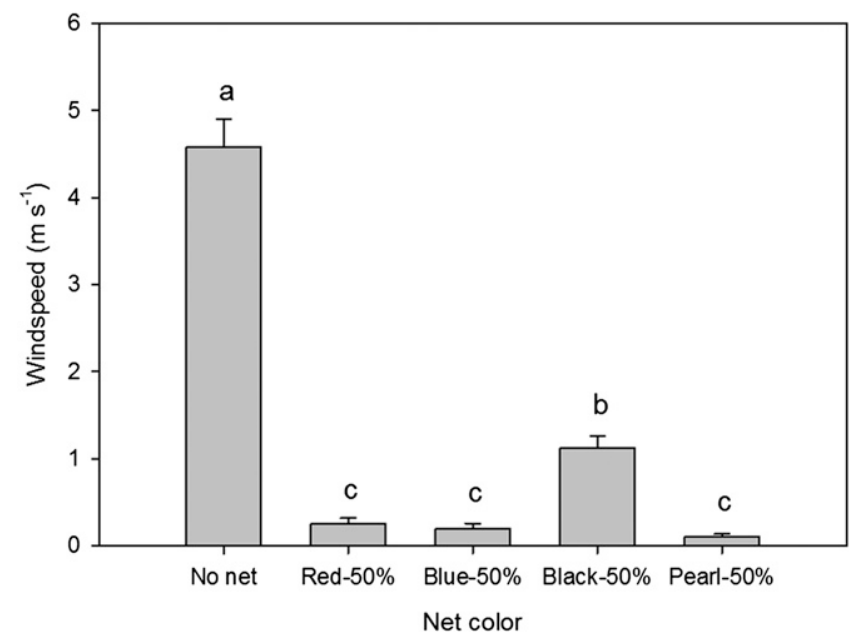

Fig. 6. Wind speeds recorded inside and outside shadehouses when ambient conditions greater than $3 \mathrm{~m} \cdot \mathrm{s}^{-1}$. Data are mean \pm SEM of 20 replicates (four houses per replicate). Letters indicate significant differences between nets $(P<0.05$, Tukey's honestly significant difference test). 
et al., 2000; Stamps, 2009). The use of colored nets might thus replace applications of chemical growth regulators or pruning practices. The tighter weaves of colored shadenets may provide additional protection from wind, hail, and animals. Our study documents the different environmental modifications inside structures covered with black and colored nets, which will help predict or interpret specific plant responses. However, a review of the literature also suggests that the responses of different plant species to modified light conditions are often variable. There is a need for additional information on how this technology is best harnessed to meet the needs of a diverse floricultural industry.

\section{Literature Cited}

Ballaré, C.L., C.A. Mazza, A.T. Austin, and R. Pierik. 2012. Canopy light and plant health. Plant Physiol. 160:145-155.

Baloch, J.U.D., M.Q. Khan, M. Zubair, and M. Munir. 2009. Effects of different shade levels (light integrals) on time to flowering of important ornamental annuals. Intl. J. Agr. Biol. 11:138144.

Basile, B., R. Romano, M. Giaccone, E. Barlotti, V. Colonna, C. Cirillo, Y. Shahak, and M. Forlani. 2008. Use of photo-selective nets for hail protection of kiwifruit vines in southern Italy. Acta Hort. 770:185-192.

Ben-Yakir, D., Y. Antignus, Y. Offir, and Y. Shahak. 2012. Colored shading nets impede insect invasion and decrease the incidences of insecttransmitted viral diseases in vegetable crops. Entomol. Exp. Appl. 144:249-257.

Castellano, S., A. Candura, and G. Scarascia Mugnozza. 2008a. Relationship between solidity ratio, colour and shading effect of agricultural nets. Acta Hort. 801:253-258.

Castellano, S., G.M. Scarascia, G. Russo, D. Briassoulis, A. Mistriotis, S. Heming, and D. Waaijenberg. 2008b. Plastic nets in agriculture: A general review of types and applications. Appl. Eng. Agr. 24:799-808.

Cohen, S. and M. Fuchs. 1999. Measuring and predicting radiometric properties of refractive shade nets and thermal screens. J. Agr. Eng. Res. 73:245-255.

Cope, K.R. and B. Bugbee. 2013. Spectral effects of three types of white light-emitting diodes on plant growth and development: Absolute versus relative amounts of blue light. HortScience 48:504-509.

Elad, Y., Y. Messika, M. Brand, D.R. David, and A. Sztejnberg. 2007. Effect of colored shade nets on pepper powdery mildew (Leveillula taurica). Phytoparasitica 35:285-299.

Fletcher, J.M., A. Tatsiopoulou, M. Mpezamihigo, J.G. Carew, R.G.C. Henbest, and P. Hadley. 2005. Far-red light filtering by plastic film, greenhouse-cladding materials: Effects on growth and flowering in Petunia and Impatiens. J. Hort. Sci. Biotechnol. 80:303-306.

Franklin, K.A. and G.C. Whitelam. 2005. Phytochromes and shade-avoidance responses in plants. Ann. Bot. (Lond.) 96:169-175.

Grantz, D.A. 1990. Plant response to atmospheric humidity. Plant Cell Environ. 13:667-679.

Ilic, Z.S., L. Milenkovic, L. Stanojevic, D. Cvetkovic, and E. Fallik. 2012. Effects of the modification of light intensity by color shade nets on yield and quality of tomato fruits. Sci. Hort. 139:90-95.

Klose, F. and H.J. Tantau. 2004. Test of insect screens. Measurements and evaluation of the air permeability and light transmission. Eur. J. Hort. Sci. 69:235-243.

Kong, Y., L. Avraham, K. Ratner, and Y. Shahak. 2012. Response of photosynthetic parameters of sweet pepper leaves to light quality manipulation by photoselective shade nets. Acta Hort. 956:501-506.

Lee, D.W., S.F. Oberbauer, P. Johnson, B. Krishnapilay, M. Mansor, H. Mohamad, and S.K. Yap. 2000 Effects of irradiance and spectral quality on leaf structure and function in seedlings of two Southeast Asian Hopea (Dipterocarpaceae) species. Amer. J. Bot. 87:447-455.

Leite, C.A., R.M. Ito, G.T.S. Lee, R. Ganelevin, and M.A. Fagnani. 2008. Light spectrum management using colored nets to control the growth and blooming of Phalaenopsis. Acta Hort. 770:177-184.

Mata, D.A. and J.F. Botto. 2009. Manipulation of light environment to produce high-quality Poinsettia plants. HortScience 44:702-706.

Moreno, J.E., Y. Tao, J. Chory, and C.L. Ballaré. 2009. Ecological modulation of plant defense via phytochrome control of jasmonate sensitivity. Proc. Natl. Acad. Sci. USA 106:49354940.

Nijskens, J., J. Deltour, S. Coutisse, and A. Nisen. 1985. Radiation transfer through covering materials, solar and thermal screens of greenhouses. Agr. For. Meteorol. 35:229-242.

Oren-Shamir, M., E. Gussakovsky, E. Shpiegel, E. Matan, I. Dory, and Y. Shahak. 2000. Colored shade nets can manipulate the vegetative growth and flowering behavior of ornamental plants. HortScience 35:503 (abst.).

Oren-Shamir, M., E.E. Gussakovsky, E. Shpiegel, A. Nissim-Levi, K. Ratner, R. Ovadia, Y.E. Giller, and Y. Shahak. 2001. Coloured shade nets can improve the yield and quality of green decorative branches of Pittosporum variegatum. J. Hort. Sci. Biotechnol. 76:353-361.

Papadakis, G., D. Briassoulis, G.M. Scaracia, G. Vox, P. Feuilloley, and J.A. Stoffers. 2000. Radiometric and thermal properties of, and testing methods for, greenhouse covering materials, Review paper. J. Agr. Eng. Res. 77:7-38.

Rajapakse, N. and J. Kelly. 1992. Regulation of Chrysanthemum growth by spectral filters. J. Amer. Soc. Hort. Sci. 17:481-485.

Retamales, J.B., J.M. Montecino, G.A. Lobos, and L.A. Rojas. 2008. Colored shading nets increase yields and profitability of highbush blueberries. Acta Hort. 770:193-197.

SAS. 2008. SAS/STAT, release 9.2 user's guide. SAS Institute, Cary, NC

Schuerger, A.C., C.S. Brown, and E.C. Stryjewski 1997. Anatomic features of pepper plants (Capsicum annuиm L.) grown under red lightemitting diodes supplemented with blue or farred light. Ann. Bot. (Lond.) 79:273-282.

Shahak, Y. 2008. Photo-selective netting for improved performance of horticultural crops. a review of ornamental and vegetable studies carried out in Israel. Acta Hort. 770:161-168.

Shahak, Y., K. Ratner, Y.E. Giller, N. Zur, E. Or, E.E. Gussakovsky, R. Stern, P. Sarig, E. Raban, E. Harcavi, I. Doron, and Y. Greenblat-Avron. 2008. Improving solar energy utilization, productivity and fruit quality in orchards and vineyards by photoselective netting. Acta Hort. 772:65-72.

Smith, H. 2000. Phytochromes and light signal perception by plants-An emerging synthesis. Nature 407:585-591.

Smith, H. and G.C. Whitelam. 1997. The shade avoidance syndrome: Multiple responses mediated by multiple phytochromes. Plant Cell Environ. 20:840-844.

Soni, P., V.M. Salokhe, and H.J. Tantau. 2005. Effect of screen mesh size on vertical temperature distribution in naturally ventilated tropical greenhouses. Biosystems Eng. 92:469-482.

Stamps, R.H. 2009. Use of colored shade netting in horticulture. HortScience 44:239-241.

Stamps, R.H. and A.L. Chandler. 2008. Differential effects of colored shade nets on three cut foliage crops. Acta Hort. 770:169-176.

Stuefer, J.F. and H. Huber. 1998. Differential effects of light quantity and spectral light quality on growth, morphology and development of two stoloniferous Potentilla species. Oecologia 117:1-8.

Takeda, F., D.M. Glenn, A. Callahan, J. Slovin, and G.W. Stutte. 2010. Delaying flowering in shortday strawberry transplants with photoselective nets. Intl. J. Fruit Sci. 10:134-142.

USDA/NASS. 2013. Floricultural crops 2012 summary. U.S. Dept. Agric., National Agric. Statistics Service (May 2012). 10 Jan. 2013. $<$ http:// usda01.library.cornell.edu/usda/current/FlorCrop/ FlorCrop-05-31-2012.pdf>

Wei, Z.F., M. Luo, C.J. Zhao, C.Y. Li, C.B. Gu, W. Wang, Y.G. Zu, T. Efferth, and Y.J. Fu. 2013. UV-Induced changes of active components and antioxidant activity in postharves pigeon pea [Cajanus cajan (L.) Millsp.] leaves. J. Agr. Food Chem. 61:1165-1171.

Went, F.W. 1953. The effect of temperature on plant growth. Annu. Rev. Plant Physiol. 4:347362.

Yorio, N.C., R. Wheeler, G. Goins, M. SanwoLewandowski, C. Mackowiak, C. Brown, J.C. Sager, and G. Stutte. 1998. Blue light requirements for crop plants used in bioregenerative life support systems. Life Support Biosph. Sci. 5:119-128. 